DOI: https://doi.org/10.24127/ajpm.v8i1.1892

\title{
EFEKTIVITAS MODEL PEMBELAJARAN VISUALIZATION AUDITORY KINESTHETIC (VAK) TERHADAP PEMAHAMAN KONSEP MATEMATIS BERDASARKAN KLASIFIKASI SELF-EFFICACY
}

\author{
Muthiah Miftahul Jannah ${ }^{1}$, Nanang Supriadi ${ }^{2}$, Fraulein Intan Suri ${ }^{3}$ \\ ${ }^{1,2,3}$ Pendidikan Matematika, Universitas Islam Negeri Raden Intan Lampung \\ E-mail: $\quad$ muthiahmiftahuljannah@gmail.com ${ }^{l)}$ \\ nanangsupriadi@radenintan.ac.id ${ }^{2)}$ \\ frauleinintan@radenintan.ac.id ${ }^{3}$
}

Received 22 February 2019; Received in revised form 4 April 2019; Accepted 10 May 2019

\begin{abstract}
Understanding mathematical concepts is one of the mathematical skills that must be mastered in learning mathematics. Self-efficacy is a feeling of confidence to solving a problem. The purpose of this study are to find out the Visualization Auditory Kinesthetic (VAK) learning model is more effective than conventional learning models, to find out the differences between students who have self-efficacy moderate and low on understanding mathematical concepts, and to know the interaction learning models and self-efficacy to wards understanding mathematical concepts. This type of research is Quasi Experimental Design. The population in this study were VII A and B grade students of MTsN 2 Bandar Lampung. Data analysis techniques used normality test with Liliefors test and homogeneity test with Bartlett test. The hypothesis test used is a two-way unequal cell ANAVA test and a further test using a double comparative test using the Scheffe method. Based on the analysis and discussion of the calculation of research data, it was concluded that: First, mathematics learning using learning models was visualization auditory kinesthetic more effective than conventional learning models for understanding mathematical concepts. Second, understanding mathematical concepts of students who have self-efficacy moderate is better than low. Third, the results of the analysis show that there is no interaction between the learning model and the classification of self-efficacy to wards understanding mathematical concepts.
\end{abstract}

Keywords: Understanding Mathematical Concepts; Self-Efficacy; Visualization Auditory Kinesthetic.

\section{PENDAHULUAN}

Pemahaman konsep adalah salah satu yang menjadi perhatian cukup besar pada bidang matematika. Hal ini disebabkan karena mata pelajaran matematika menekankan pada konsep. Pemahaman konsep matematis juga menjadi hal yang paling mendasar untuk dapat berkembangnya materi lebih lanjut, dengan memahami dan menerapkan konsep yang telah dipelajari, maka peserta didik dapat mengembangkan kemampuannya untuk menyelesaikan permasalahan dari yang sederhana hingga yang kompleks (Murizal, 2012).

Pembelajaran matematika memiliki beberapa tujuan, seperti yang telah disusun oleh Pemerintah melalui Badan Standar Nasional Pendidikan (BSNP) terdapat dalam Permendiknas No. 22 Tahun 2006, yaitu agar peserta didik memiliki kemampuan untuk: (1) memahami konsep matematika, menjelaskan keterkaitan antar konsep, dan mengaplikasikan secara akurat, efisien dan tepat dalam pemecahan masalah; (2) menggunakan penalaran pada pola dan sifat, menyusun bukti, atau menjelaskan pernyataan matematika; (3) memecahkan masalah yang meliputi kemampuan memahami masalah, merancang model matematika, menyelesaikan model, dan menafsirkan solusi yang diperoleh; (4) mengkomunikasikan gagasan dengan 
simbol, tabel, diagram, atau media lain untuk memperjelas keadaan atau masalah; (5) memiliki sikap menghargai kegunaan matematika dalam kehidupan, yaitu rasa ingin tahu, perhatian, dan minat dalam mempelajari matematika, serta sikap ulet dan percaya diri dalam pemecahan masalah (Supriadi, 2015) .

Berdasarkan tujuan pembelajaran di atas, pemahaman konsep matematis menjadi aspek yang sangat penting. Melalui pemahaman, maka akan lebih mengerti konsep dari materi pelajaran itu sendiri. Pemahaman konsep matematika artinya mengerti benar tentang konsep matematika, yaitu peserta didik dapat menerjemahkan, menafsirkan, dan menyimpulkan suatu konsep matematika berdasarkan pembentukan pengetahuannya sendiri, bukan sekedar menghafal. Pemahaman terhadap konsep-konsep matematika merupakan dasar untuk belajar matematika secara bermakna (Setyaningrum, Hendikawati, \& Nugroho, 2018).

Kemampuan pemahaman konsep matematis saja tidak cukup sebagai bekal peserta didik untuk mencapai keberhasilannya menyelesaikan persoalan pada pelajaran matematika dengan baik, maka perlu peningkatan pada sisi afektif, salah satunya adalah efikasi diri (self efficacy). Self Efficacy merupakan rasa keyakinan pada diri seseorang dalam menghadapi dan menyelesaikan masalah. Self efficacy juga perlu diperhatikan, agar matematika lebih menyenangkan bagi peserta didik. Ditinjau dari akademik, Self efficacy mengacu pada keyakinan individu bahwa ia mampu melakukan tindakan tertentu (Subaidi, 2016). Bandura menjelaskan bahwa self efficacy adalah berfokus pada keyakinan terhadap pelaksanaan tugas dengan baik yang berhubungan perspektif situasi. Self efficacy yang terus dilatih, membuat peserta didik mempunyai pemikiran bagaimana dia merasa, berpikir, memotivasi diri, dan berperilaku dalam menyelesaikan suatu permasalahan (Juhrani, Suyitno, \& Khumaedi, 2017).

Menurut pernyataan Bandura, peserta didik yang memiliki self efficacy tinggi memilih untuk melakukan usaha lebih besar dan tidak mudah putus asa, sehingga menjadikan tugas yang sulit dianggap sebagai tantangan untuk dipecahkan. Sedangkan peserta didik yang memiliki self efficacy rendah cenderung mudah mengalami kesulitan dalam memecahkan masalah dan mengganggap tugas tersebut sebagai ancaman terhadap dirinya, sehingga cenderung mudah menyerah (Subaidi, 2016). Selain itu, berdasarkan penelitian Hamidah, bahwa self-efficacy yang dimiliki seseorang memberi pengaruh yang besar terhadap kemampuan komunikasi matematik, artinya semakin tinggi self-efficacy seseorang terhadap kemampuan yang dimilikinya baik dalam merumuskan konsep, menyampaikan ide, dan mempertajam ide untuk meyakinkan orang lain, maka semakin tinggi pula kemampuan komunikasi matematiknya, begitupun sebaliknya (Hamidah, 2018)

Namun, pada kenyataannya masih banyak peserta didik yang memiliki konsep matematis rendah. Permasalahan mengenai rendahnya kemampuan dalam memahami konsep matematika ini ditemukan pula di MTs Negeri 2 Bandar Lampung. Rendahnya pemahaman konsep matematis yang diperoleh peserta didik ini disebabkan oleh berbagai macam faktor. Hasil wawancara yang telah dilakukan kepada pendidik, didapat informasi bahwa proses pembelajaran di sekolah masih menggunakan model pembelajaran konvensional, sehingga masih berpusat pada pendidik. Selain itu kebanyakan 
peserta didik juga masih beranggapan bahwa matematika adalah mata pelajaran yang paling ditakuti oleh sebagian peserta didik sehingga cenderung pasif saat proses pembelajaran, masih banyak peserta didik yang kesulitan dalam memahami konsep pada matematika sehingga belum mampu mengaplikasikan dengan benar pada soal, dan masih kurangnya keyakinan pada diri peserta didik akan kemampuannya dalam menyelesaikan tugas dengan benar. Hal ini yang diduga menjadi faktor penyebab pemahaman konsep matematis peserta didik menjadi rendah.

Berdasarkan uraian di atas, maka dalam proses pembelajaran perlu adanya perubahan dengan mencari model pembelajaran yang menarik untuk diterapkan. Diantara banyaknya model pembelajaran yang diketahui, salah satu sarana untuk dapat meningkatkan pemahaman konsep matematis dan efikasi diri (self efficacy) peserta didik adalah dengan menerapkan model pembelajaran Visualization Auditory Kinestethic (VAK). Model pembelajaran Visualization Auditory Kinestethic (VAK) adalah model pembelajaran yang difokuskan pada pemberian pengalaman belajar secara langsung (direct experience) dan menyenangkan menggunakan cara belajar dengan melihat (visual), belajar dengan mendengar (auditory), dan belajar dengan bergerak serta emosi (kinesthetic) (H. Pratiwi, 2015). Model pembelajaran ini memiliki beberapa kelebihan, diantaranya pembelajaran akan lebih efektif, memunculkan suasana belajar yang lebih menarik, mampu melibatkan peserta didik secara maksimal dalam memahami suatu konsep melalui kegiatan fisik, seperti percobaan, observasi, diskusi aktif, dan lain sebagainya (Wibowo, 2017). Hal ini didukung dengan penelitian yang dilakukan sebelumnya oleh Agus Tri Wibowo, bahwa terdapat pengaruh yang positif dan signifikan pada penggunaan model pembelajaran visual auditory kinesthetic (VAK) terhadap hasil belajar matematika siswa (Wibowo, 2017). Selain itu juga penelitian yang dilakukan oleh Ade Lestari, bahwa aktifitas peserta didik dalam belajar matematika selama diterapkannya strategi pembelajaran berbasis gaya belajar VAK cenderung meningkat (Lestari, 2012).

Tujuan penelitian ini adalah sebagai berikut: 1) Untuk mengetahui pembelajaran matematika dengan menggunakan model pembelajaran Visualization Auditory Kinesthetic (VAK) lebih efektif dari pada model pembelajaran konvensional. 2) Untuk mengetahui adanya perbedaan antara peserta didik yang memiliki self efficacy sedang dan rendah terhadap pemahaman konsep matematis. 3) Untuk mengetahui adanya interaksi antara model pembelajaran dan self efficacy peserta didik terhadap pemahaman konsep matematis.

\section{METODE PENELITIAN}

Jenis metode penelitian yang digunakan adalah Quasi Experimental Design. Penelitian ini dikelompokkan menjadi dua kelompok, kelompok pertama adalah kelompok eksperimen, yaitu peserta didik mendapat perlakuan pembelajaran matematika dengan model pembelajaran VAK (Visualization, Auditory, Kinesthetic). Sedangkan kelompok kedua adalah kelompok kontrol, yaitu peserta didik mendapat perlakuan pembelajaran matematika dengan model konvensional. Populasi dalam penelitian ini adalah peserta didik kelas VII di MTs Negeri 2 Bandar Lampung. Sampel dalam penelitian ini 
terdiri dari dua kelas yaitu kelas VII A sebagai kelas eksperimen yang berisi 33 peserta didik dan kelas VII I sebagai kelas kontrol yang berisi 30 peserta didik.

Penelitian ini terdapat dua variabel bebas yaitu model pembelajaran visualization auditory kinesthetic (VAK) dan self-efficacy serta satu variabel terikat yaitu pemahaman konsep matematis. Instrumen yang digunakan pada penelitian ini berupa tes pemahaman konsep matematis dan angket selfefficacy peserta didik. Adapun indikator pemahaman konsep matematis adalah sebagai berikut:

1. Menyatakan ulang setiap konsep

2. Mengklasifikasikan objek-objek menurut sifat-sifat tertentu (sesuai dengan konsepnya).

3. Memberikan contoh dan non contoh dari konsep

4. Menyajikan konsep dalam berbagai bentuk representasi matematis.
5. Mengembangkan syarat perlu dan syarat cukup suatu konsep.

6. Menggunakan, memanfaatkan, dan memilih prosedur atau operasi tertentu.

7. Mengaplikasikan konsep atau algoritma pemecahan masalah. (D. D. Pratiwi, 2016).

Sedangkan indikator self-efficacy pada penelitian ini menggunakan indikator yang dikembangkan dari dimensi self-efficacy menurut Bandura, yaitu sebagai berikut:

1. Keyakinan terhadap kemampuan diri sendiri.

2. Keyakinan terhadap kemampuan menyesuaikan dan menghadapi tugas-tugas yang sulit.

3. Keyakinan terhadap kemampuan dalam menghadapi tantangan.

4. Keyakinan terhadap kemampuaan menyelesaikan tugas yang spesifik.

5. Keyakinan terhadap kemampuan menyelesaikan beberapa tugas yang berbeda. (Subaidi, 2016)

Tabel 1. Deskripsi Data Hasil Posttest Pemahaman Konsep Matematis

\begin{tabular}{lcccrrrr}
\hline \multirow{2}{*}{ Kelompok } & \multirow{2}{*}{$\mathrm{X}_{\max }$} & $\mathrm{X}_{\min }$ & \multicolumn{3}{c}{ Ukuran Tendensi Sentral } & \multicolumn{2}{c}{ Ukuran Variansi } \\
& & & $\overline{\mathrm{X}}$ & $\mathrm{M}_{\mathrm{o}}$ & $\mathrm{M}_{\mathrm{e}}$ & $\mathrm{R}$ & $\mathrm{Sd}$ \\
\hline Eksperimen & 100 & 78,57 & 90,363 & 85,71 & 89,28 & 21,43 & 6,344 \\
Kontrol & 100 & 64,28 & 80.711 & 78,57 & 78,57 & 35,72 & 8,421 \\
\hline
\end{tabular}

Berdasarkan Tabel 1, diperoleh bahwa nilai tertinggi pada kelas eksperimen sebesar 100 dan kelas kontrol dengan nilai yang sama yaitu 100, sedangkan nilai terendah pada kelas eksperimen yaitu 78,57 dan kelas kontrol yaitu 64,28. Nilai rata-rata (mean) pada kelas eksperimen adalah 90,363 lebih besar dari nilai rata-rata kelas kontrol yaitu 80,711. Data di atas dapat disimpulkan bahwa deskripsi data kelas eksperimen
Uji coba instrumen penelitian meliputi uji validitas, uji reliabilitas, uji tingkat kesukaran, dan uji daya pembeda. Teknik analisis data menggunakan uji normalitas dengan uji Liliefors dan uji homogenitas dengan uji Bartlett. Uji hipotesis yang digunakan yaitu uji ANAVA dua jalan sel tak sama dan uji lanjut menggunakan uji komparasi ganda dengan menggunakan metode Scheffe. 
DOI: https://doi.org/10.24127/ajpm.v8i1.1892

\section{HASIL PENELITIAN DAN PEMBAHASAN}

Berdasarkan data hasil penelitian, diperoleh data hasil posttest pemahaman konsep matematis kelas eksperimen dan kontrol. Deskripsi data hasil posttest pemahaman konsep matematis dapat dilihat pada Tabel 1. Pada Tabel 1 terlihat bahwa kelas eksperimen memperoleh hasil lebih tinggi daripada kelas kontrol.
Selain itu data angket selfefficacy didapat dari angket yang telah diberikan kepada peserta didik. Berdasarkan data yang telah terkumpul, peserta didik akan digolongkan ke dalam 3 klasifikasi self- efficacy untuk kelas eksperimen dan kelas kontrol. Klasifikasi self-efficacy dapat dilihat pada Tabel 2.

Tabel 2. Klasifikasi Self-Efficacy

\begin{tabular}{cc}
\hline Batas Nilai & Keterangan \\
\hline$x \geq 87,19$ & Tinggi \\
$66,524<x<87,19$ & Sedang \\
$x \leq 66,524$ & Rendah \\
\hline
\end{tabular}

Tabel 3. Deskripsi Hasil Angket Self-Efficacy

\begin{tabular}{llcc}
\hline \multirow{2}{*}{ Model Pembelajaran $\left(\mathrm{A}_{\mathrm{i}}\right)$} & & \multicolumn{2}{c}{ Self Efficacy $\left(\mathrm{B}_{\mathrm{i}}\right)$} \\
& & Sedang $\left(\mathrm{B}_{2}\right)$ & Rendah $\left(\mathrm{B}_{3}\right)$ \\
\hline Visualization Euditory Kinesthetic & $\mathrm{N}$ & 22 & 3 \\
$\left(\mathrm{~A}_{1}\right)$ & $\mathrm{X}_{\max }$ & 86 & 66 \\
& $\mathrm{X}_{\min }$ & 68 & 63 \\
& $\overline{\mathrm{X}}$ & 77,091 & 65 \\
\multirow{3}{*}{ Konvensional $\left(\mathrm{A}_{2}\right)$} & $\mathrm{S}$ & 5,639 & 1,732 \\
& $\mathrm{~N}$ & 15 & 9 \\
& $\mathrm{X}_{\max }$ & 79 & 66 \\
& $\mathrm{X}_{\min }$ & 69 & 56 \\
& $\mathrm{X}$ & 73,267 & 62,889 \\
& $\mathrm{~S}$ & 3,348 & 3,983 \\
\hline
\end{tabular}

Berdasarkan Tabel 3, diperoleh data pada kelas eksperimen yaitu peserta didik yang memiliki selfefficacy self-efficacy sedang sebanyak 22 orang dengan rata-rata 77,091 dan simpangan baku 5,639, dan peserta didik yang memiliki self-efficacy rendah sebanyak 3 orang dengan rata-rata 65 dan simpangan baku 1,732. Sedangkan pada kelas kontrol peserta didik yang memiliki self-efficacy sedang sebanyak 15 orang dengan rata-rata 73,267 dan simpangan baku 3,348, dan peserta didik yang memiliki self-efficacy rendah sebanyak 9 orang dengan rata-rata 62,889 dan simpangan baku 3,983.

Berdasarkan data yang ditampilkan pada Tabel 3 dapat disimpulkan bahwa nilai yang diperoleh dari penerapan model pembelajaran visualization auditory kinesthetic lebih tinggi daripada model pembelajaran konvensional. Selain itu, uji hipotesis dalam penelitian ini menggunakan uji analisis variansi (ANAVA) dua jalan dengan sel tak sama. Hasil perhitungannya dapat dilihat pada Tabel 4. 
DOI: https://doi.org/10.24127/ajpm.v8i1.1892

Tabel 4. Rangkuman Analisis Variansi Dua Jalan

\begin{tabular}{cccccc}
\hline Sumber & JK & Dk & RK & $\mathrm{F}_{\text {Hitung }}$ & $\mathrm{F}_{\text {Tabel }}$ \\
\hline Perlakuan (A) & 563,561 & 1 & 563,561 & 39,533 & 4,010 \\
Self-efficacy (B) & 2792,370 & 2 & 1396,18 & 97,939 & 3,159 \\
Interaksi (AB) & 6,764 & 2 & 3,382 & 0,237 & 3,159 \\
Galat & 812,570 & 57 & 14,256 & - & - \\
\hline Total & 4175,264 & 62 & - & - & - \\
\hline
\end{tabular}

Berdasarkan perhitungan analisis data seperti yang ditampilkan pada Tabel 4 tersebut dapat disimpulkan bahwa:

1) $\mathrm{F}_{\mathrm{a}}=39,533$ dan taraf signifikansi $5 \%$ diperoleh $\mathrm{F}_{(0,05 ; 1 ; 57)}=4,010$ sehingga $\quad \mathrm{F}_{\mathrm{a}}>F_{(0,05 ; 1 ; 57)}$ yang menunjukan bahwa $\mathrm{H}_{0 \mathrm{~A}}$ ditolak berarti terdapat perbedaan antara model pembelajaran visualization auditory kinesthetic dengan pembelajaran konvensional. Sehingga, model pembelajaran visualization auditory kinesthetic lebih efektif dari pada model pembelajaran konvensional.

2) $F_{b}=97,939$ dan taraf signifikansi $5 \%$ diperoleh $\mathrm{F}_{(0,05 ; 1 ; 57)}=3,159$ sehingga

$\mathrm{F}_{\mathrm{b}}>\mathrm{F}_{(0,05 ; 2 ; 57)}$ yang menunjukan bahwa $\mathrm{H}_{0 \mathrm{~B}}$ ditolak berarti terdapat perbedaan antara peserta didik yang memiliki self-efficacy sedang dan rendah terhadap pemahaman konsep matematis.

3) $\mathrm{F}_{\mathrm{ab}}=0,237$ dan taraf signifikansi $5 \%$ diperoleh $\mathrm{F}_{(0,05 ; 2 ; 57)}=3,159$ sehingga $\mathrm{F}_{\mathrm{ab}}<\mathrm{F}_{(0,05 ; 2 ; 57)}$ yang menunjukan bahwa $\mathrm{H}_{0 \mathrm{AB}}$ diterima berarti tidak ada interaksi antara model pembelajaran dan selfefficacy terhadap pemahaman konsep matematis peserta didik.

Kemudian, uji lanjut yang digunakan pada penelitian ini adalah Metode scheffe', uji ini dilakukan untuk hipotesis yang ditolak. Data rekapitulasi rataan marginalnya ditampilkan pada Tabel 5.

Tabel 5. Rataan Marginal

\begin{tabular}{|c|c|c|c|}
\hline \multirow{2}{*}{$\begin{array}{c}\text { Model } \\
\text { Pembelajaran }\end{array}$} & \multicolumn{2}{|c|}{ Self-Efficacy } & \multirow{2}{*}{ Rataan Marginal } \\
\hline & Sedang & Rendah & \\
\hline VAK & 88,793 & 79,76 & 84,277 \\
\hline Konvensional & 81,664 & 71,424 & 76,544 \\
\hline Rataan Marginal & 85,229 & 75,592 & \\
\hline
\end{tabular}

Berdasarkan hasil perhitungan uji ANAVA (Tabel 4), diperoleh bahwa $\mathrm{H}_{0 \mathrm{~A}}$ ditolak. Untuk mengetahui model pembelajaran manakah yang lebih baik cukup dengan membandingkan besarnya rataan marginal dari masingmasing model pembelajaran. Rataan marginal pada model pembelajaran visualization auditory kinesthetic sebesar 84,277 yang berarti memiliki interprestasi lebih tinggi dibandingkan dengan rataan marginal pada pembelajaran konvensional yaitu sebesar 76,544. Sehingga, dapat disimpulkan bahwa pemahaman konsep matematis dengan menggunakan model pembelajaran visualization auditory kinesthetic lebih baik dari pembelajaran konvensional. 
Hasil perhitungan uji ANAVA (Tabel 4) juga diperoleh bahwa $\mathrm{H}_{0 \mathrm{~B}}$ ditolak dan karena memiliki 3 klasifikasi self-efficacy maka diperlukan uji komparasi ganda antar kolom dengan menggunakan metode scheffe'. Hasil uji komparasi ganda antar kolom pada masing-masing klasifikasi selfefficacy dapat dilihat pada Tabel 6.

Tabel 6. Uji Komparasi Ganda Antar Kolom

\begin{tabular}{cccc}
\hline Interaksi & $\mathrm{F}_{\text {hitung }}$ & $\mathrm{F}_{\text {tabel }}$ & Kesimpulan \\
\hline$\mu_{2}$ vs $\mu_{3}$ & 273,696 & 6,318 & $\mathrm{H}_{0}$ Ditolak \\
\hline
\end{tabular}

Berdasarkan Tabel 6 diperoleh bahwa: $\mu_{2}$ vs $\mu_{3}$, menunjukkan bahwa $F_{\text {hitung }}<F_{\text {tabel }}$ dengan nilai $F_{\text {hitung }}=$ 273,696 dan $F_{\text {tabel }}=6,318$. Sehingga $\mathrm{H}_{0}$ ditolak artinya terdapat perbedaan terhadap pemahaman konsep matematis antara peserta didik yang memiliki selfefficacy sedang dengan peserta didik yang memiliki self-efficacy rendah. Berdasarkan rataan marginal pemahaman konsep matematis pada peserta didik dengan self-efficacy sedang sebesar 85,229 sedangkan rataan marginal pemahaman konsep matematis pada peserta didik dengan self-efficacy rendah sebesar 75,592. Sehingga peserta didik dengan self-efficacy sedang pemahaman konsep matematisnya lebih baik dari pada peserta didik yang memiliki self-efficacy rendah. Selanjutnya karena $\mathrm{H}_{0 \mathrm{AB}}$ diterima artinya tidak terdapat interaksi antara model pembelajaran dan self efficacy peserta didik terhadap pemahaman konsep matematis. Karena tidak ada interaksi antara model pembelajaran dan self efficacy peserta didik, maka tidak perlu dilakukan uji komparasi ganda antar sel pada baris maupun kolom yang sama.

Perhitungan hipotesis menggunakan rumus ANAVA dua jalan sel tak sama menghasilkan hipotesis pertama yang menyatakan bahwa, terdapat perbedaan antara model pembelajaran visualization auditory kinesthetic dengan model pembelajaran konvensional. Hasil yang diperoleh dapat disimpulkan bahwa, pembelajaran matematika dengan menggunakan model pembelajaran visualization auditory kinesthetic lebih efektif daripada menggunakan model pembelajaran konvensional terhadap pemahaman konsep matematis. Untuk melihat perbedaan tersebut, dapat membandingkan rataan marginal setiap model pembelajaran. Rataan marginal pada model pembelajaran visualization auditory kinesthetic adalah sebesar 84,227 . Sedangkan rataan marginal pada pembelajaran konvensional sebesar 76,544, yang artinya model pembelajaran visualization auditory kinesthetic memiliki interprestasi pemahaman konsep matematis lebih tinggi.

Hasil di atas dikarenakan model pembelajaran visualization auditory kinesthetic dapat membuat suasana belajar menjadi aktif dan menyenangkan sehingga peserta didik terlihat antusias pada saat proses pembelajaran berlangsung. Sesuai dengan kelebihan dari model pembelajaran visualization auditory kinesthetic yang dikatakan oleh Russel, bahwa kegiatan pembelajaran akan lebih efektif karena mengkombinasikan ketiga gaya belajar, memunculkan suasana belajar yang lebih baik, menarik, dan efektif, selain itu memberikan pengalaman langsung dengan melibatkan peserta didik secara maksimal dalam memahami konsep, dan lain-lain. Model pembelajaran visualization auditory kinesthetic membuat peserta didik merasa tidak kesulitan dalam memahami suatu konsep karena melibatkan peserta didik secara maksimal selama proses 
pembelajaran berlangsung sekaligus dapat melatih peserta didik dalam memahami konsep dengan baik.

Berdasarkan hal tersebut, peserta didik dengan diterapkan model pembelajaran visualization auditory kinesthetic menghasilkan pemahaman konsep matematis yang lebih baik daripada peserta didik yang diterapkan dengan pembelajaran konvensional. Sehingga sesuai dengan hasil penelitian yang diperoleh, dapat disimpulkan bahwa pemahaman konsep matematis dengan menggunakan model pembelajaran visualization auditory kinesthetic lebih efektif dibandingkan pemahaman konsep matematis dengan menggunakan model konvensional.

Hal ini sesuai dengan penelitian sebelumnya yang telah dilakukan oleh Agus Tri Wibowo (2017), bahwa terdapat pengaruh yang positif dan signifikan pada model pembelajaran visualization auditory kinesthetic terhadap hasil belajar matematika siswa (Wibowo, 2017). Selain itu, penelitian yang dilakukan oleh (Rahmawati, Buchori, \& Hermawan (2018), yang menyimpulkan bahwa model Visualization Auditory Kinestethic (VAK) baik untuk meningkatkan hasil belajar (Rahmawati, Buchori, \& Hermawan, 2017).

Perhitungan

hipotesis

menggunakan rumus ANAVA dua jalan sel tak sama, menghasilkan hipotesis kedua yang menyatakan bahwa, terdapat perbedaan pemahaman konsep matematis peserta didik yang memiliki self-efficacy sedang dan rendah karena $F_{\text {hitung }}>F_{\text {tabel }}$ yang menunjukan bahwa $\mathrm{H}_{0}$ ditolak. Hasil dari perhitungan uji komparasi ganda antar kolom dengan menggunakan metode scheffe', diperoleh bahwa pemahaman konsep matematis peserta didik yang memiliki self-efficacy sedang lebih baik dibandingkan dengan peserta didik yang memiliki self-efficacy rendah. Untuk melihat hal tersebut, dapat membandingkan rataan marginal dari tiap klasifikasi self efficacy. Rataan marginal pada self efficacy sedang sebesar 85,229 sedangkan rataan marginal pada self efficacy rendah adalah 75,592. Artinya, klasifikasi self efficacy sedang memiliki interprestasi pemahaman konsep matematis lebih baik dibandingkan self efficacy rendah. Hal ini disebabkan karena peserta didik yang memiliki self-efficacy sedang lebih yakin akan kemampuan dirinya dan melakukan usaha lebih besar untuk dapat menyelesaikan tugasnya meskipun terasa sulit, sehingga cenderung tidak mudah putus asa dan pantang menyerah.

Penelitian ini sejalan dengan hasil penelitian yang telah dilakukan sebelumnya oleh Febrina Handayani (2013) yang menyimpukan bahwa ada hubungan antara self efficacy dengan prestasi belajar peserta didik. Semakin tinggi self efficacy yang dimiliki oleh peserta didik maka semakin tinggi pula prestasi belajar yang didapatkan. Sebaliknya jika self efficacy yang dimiliki oleh peserta didik rendah, maka semakin rendah pula prestasi belajar yang didapatkan. Peserta didik yang memiliki self efficacy yang tinggi memiliki keyakinan dalam menghadapi tugas-tugas yang sulit dengan berbagai situasi. Self efficacy yang tinggi dapat meyakinkan peserta didik dalam usaha meningkatkan prestasi belajarnya (Handayani, 2013). Selain itu penelitian sebelumnya yang dilakukan oleh Hamidah (2018) bahwa self efficacy yang dimiliki seseorang memberi pengaruh yang besar terhadap kemampuan matematisnya, artinya semakin tinggi self efficacy seseorang terhadap kemampuan yang dimilikinya baik dalam merumuskan konsep, menyampaikan ide, dan mempertajam 
ide untuk meyakinkan oranglain, maka akan semakin tinggi pula kemampuan matematisnya, begitupun sebaliknya (Hamidah, 2018).

Perhitungan hipotesis menggunakan rumus ANAVA dua jalan sel tak sama menghasilkan hipotesis ketiga yang menyatakan bahwa tidak ada interaksi antara model pembelajaran dan self-efficacy terhadap pemahaman konsep matematis peserta didik, karena $F_{\text {hitung }}<F_{\text {tabel }}$ yang menunjukan bahwa $\mathrm{H}_{0}$ diterima. Maka klasifikasi self-efficacy peserta didik terhadap pemahaman konsep matematis akan sama pada setiap treatment pembelajaran yang dilakukan.

\section{KESIMPULAN DAN SARAN}

Berdasarkan hasil analisis dan pembahasan yang diperoleh dari data penelitian, disimpulkan bahwa: Pertama, pembelajaran matematika dengan menggunakan model pembelajaran visualization auditory kinesthetic lebih efektif daripada menggunakan model pembelajaran konvensional terhadap pemahaman konsep matematis. Kedua, terdapat perbedaan pemahaman konsep matematis peserta didik yang memiliki klasifikasi self-efficacy sedang dan rendah. Pemahaman peserta didik yang memiliki klasifikasi self-efficacy sedang lebih baik dibandingkan klasifikasi selfefficacy rendah. Ketiga, tidak terdapat interaksi antara model pembelajaran dan self-efficacy terhadap pemahaman konsep matematis peserta didik.

Berdasarkan hasil penelitian dan beberapa temuan dilapangan, penulis menyarankan hal-hal sebagai berikut: Model pembelajaran Visualization Auditory Kinesthetic (VAK) dapat membuat suasana belajar yang menyenangkan, karena penerapannya dengan mengkombinasikan tiga gaya belajar dalam satu waktu. Sehingga disarankan untuk menerapkan model pembelajaran ini, agar fokus gaya belajar yang berbeda-beda pada peserta didik mampu mengaktifkan sisi gaya belajar yang lainnya. Kemudian variasi tingkat kesukaran pada soal tidak menjadi permasalahan dengan diterapkannya model pembelajaran Visualization Auditory Kinesthetic (VAK) ini, karena jika proses pembelajaran disajikan dengan menarik, maka peserta didik tidak merasa terbebani dalam menyelesaikan soal yang diberikan. Selain itu model pembelajaran Visualization Auditory Kinesthetic (VAK) dapat meningkatkan keterlibatan peserta didik dalam aktifitas pembelajaran. Oleh karena itu, disarankan kepada pendidik untuk menerapkan model pembelajaran visualization auditory kinesthetic (VAK) sebagai alternatif dan variasi suasana belajar yang dapat meningkatkan pemahaman konsep matematis peserta didik, dan bagi penelitian selanjutnya, disarankan untuk melihat peningkatan setiap indikator pemahaman konsep matematis juga kemampuan lainnya yang bisa diterapkan melalui model pembelajaran visualization auditory kinesthetic (VAK). Semoga apa yang telah diteliti dapat memberikan manfaat serta sumbangan pemikiran baik untuk pendidik pada umumnya.

\section{DAFTAR PUSTAKA}

Hamidah. (2018). "Pengaruh Self Efficacy terhadap Kemampuan Komunikasi Matematik”, diakses di. http://seminar.uny.ac.id.

Handayani, Febrina. (2013). "Hubungan Self Efficacy dengan Prestasi Belajar Siswa 
DOI: https://doi.org/10.24127/ajpm.v8i1.1892

Akselerasi”, Jurnal Mahasiswa Unesa 1(2).

Juhrani, J., Suyitno, H., \& Khumaedi, K. (2017). Analisis Kemampuan Komunikasi Matematis Berdasarkan Self-Efficacy Siswa pada Model Pembelajaran Mea. Unnes Journal of Mathematics Education Research, 6(2), 251258.

Lestari, A. (2012). Penerapan Strategi Pembelajaran Matematika Berbasis Gaya Belajar Vak (Visual, Auditorial, Kinestetik). Jurnal Pendidikan Matematika, 1(1).

Murizal, A. (2012). Pemahaman Konsep Matematis dan Model Pembelajaran Quantum Teaching. Jurnal Pendidikan Matematika, 1(1).

Pratiwi, D. D. (2016). Pembelajaran Learning Cycle 5E berbantuan Geogebra terhadap Kemampuan Pemahaman Konsep Matematis. Al-Jabar: Jurnal Pendidikan Matematika, 7(2), 191-202.

Pratiwi, H. (2015). Penerapan Model Visualization, Auditory, Kinesthetic (Vak) Dengan Multimedia Untuk Meningkatkan Pembelajaran Matematika Tentang Bangun Ruang Pada Siswa Kelas V SDN 2 Tamanwinangun Tahun Ajaran 2014/2015. Kalam Cendekia 3(3.1), 320-325.

Rahmawati, N. D., Buchori, A., \& Hermawan, J. S. (2017). Efektivitas Visualization Auditory Kinestetic Dan Two Stay Two Stray Berbantuan Lectora Terhadap Hasil Belajar Matematika Siswa SMA. Jurnal Ilmiah Pendidikan Matematika 2(2), 152-164.

Setyaningrum, V. F., Hendikawati, P., \& Nugroho, S. (2018).
Peningkatan Pemahaman Konsep dan Kerja Sama Siswa Kelas X Melalui Model Discovery Learning. PRISMA, Prosiding Seminar Nasional Matematika, 1, 810-813.

Subaidi, A. (2016). Self-Efficacy Siswa Dalam Pemecahan Masalah Matematika. Jurnal Sigma, 1(2), 64-68.

Supriadi, N. (2015). Pembelajaran Geometri Berbasis Geogebra Sebagai Upaya Meningkatkan Kemampuan Komunikasi Matematis Siswa Madrasah Tsanawiyah (MTs). Al-Jabar: Jurnal Pendidikan Matematika, 6(2), 99-110.

Wibowo, A. T., Sarengat, \& Astuti, N. (2017). Pengaruh Model Pembelajaran Visual Auditory Kinesthetic Terhadap Hasil Belajar Matematika Siswa SD. Jurnal Pedagogi 6(4). 